\title{
Lugares do Catolicismo Negro na São Paulo do século XIX
}

FABRÍCIO FORGANES SANTOS ${ }^{I}$

\section{Introdução}

$\mathrm{A}$ PARTE que cabia à Igreja, na sua relação intrínseca com a Coroa de Portugal, incluía o apoio na introdução da mão de obra escrava negra, controlando esses "gentios" por intermédio da catequização. O costume de incitar nesses escravizados o interesse pela adesão às irmandades leigas, além de contribuir para a eficácia da conversão, favoreceria a vigilância desses indivíduos, compelindo o entorno das igrejas como lugar para a construção de suas redes de sociabilidade no contexto urbano. No Brasil, essa estratégia já legitimaria a ambiência dos templos católicos como gênese da presença urbana negra nas cidades fundadas a partir da colonização portuguesa.

Contudo, sob a óptica da diáspora africana, há hipóteses de que o estabelecimento adjacente às igrejas católicas poderia ter como justificativa a continuidade de uma prática religiosa iniciada antes do cativeiro (Thornton, 2004, p.335), sentimento despertado ao menos para parte desses escravizados, cuja convivência com o catolicismo seria anterior à travessia do Atlântico. Partindo desse pressuposto, ainda que tal condição seja resultante de um longo processo de conformação do cristianismo na África, interessa recuperar a parte dessa narrativa que trata da constituição dos territórios católicos nas terras africanas colonizadas por portugueses. Com este breve preâmbulo, para além de identificar os lugares do catolicismo negro na cidade de São Paulo, este artigo pretende despertar reflexões acerca das possíveis motivações para o estabelecimento e a defesa dos "malungos" ante esses locais, favorecendo, sobretudo, a compreensão da importância simbólica desses enclaves urbanos para o povo negro paulista.

\section{Territórios do catolicismo na África}

Ainda no primeiro quartel do século $\mathrm{XV}$, a busca pelas riquezas africanas, realizada sob as bençãos das autoridades papais, ${ }^{2}$ levaria os portugueses a sucessivas incursões na costa ocidental e parte insular localizadas nos limites geográficos deste continente. Embora estabelecidas nos anos que seguiram a colonização dessas ilhas, a presença de igrejas nesses lugares, ${ }^{3}$ bem como de irmandades dedicadas a Nossa Senhora do Rosário desde 1526 (Fonseca, 2016, p.69), além de sugerir uma possível circulação de clérigos nessas regiões, revelaria a existência de territórios católicos na África, em pontos estratégicos utilizados posteriormente no apoio as atividades do tráfico atlântico de escravos. 
A colonização portuguesa na Costa da Mina daria início à espacialização do catolicismo na África Negra. O encontro dos garimpos de ouro aceleraria o interesse no estabelecimento de bases de controle, favorecendo a construção do Castelo de São Jorge da Mina - testemunho da presença portuguesa no Golfo da Guiné - e, consequentemente, instituindo um povoado onde se daria a fundação de um convento religioso. ${ }^{4} \mathrm{O}$ lugar seria frequentado majoritariamente por europeus destinados às atividades do comércio escravista; contudo sendo o marco inicial na conquista do interior dessas terras africanas, se configuraria como ponto de origem no itinerário de religiosos à conversão dos habitantes iorubás, povos que viviam em impérios bem constituídos como o Reino do Edo (Meredith, 2017, p.117). Provavelmente nas trocas comerciais entre as autoridades portuguesas e africanas, realizadas nesse período, haveria o contato desses povos com o catolicismo; mesmo assim não foram identificadas assimilações relevantes nesses lugares, possivelmente porque a tradição religiosa de culto aos diferentes orixás não encontraria paralelo com a devoção estrangeira apresentada. ${ }^{5}$

Diferente do que acontecera com os iorubás, o catolicismo teria melhores desdobramentos na sua circulação pelos povos bantos, em parte pela possível correlação entre os ícones e dogmas da prática europeia e os fundamentos e símbolos da religião tradicional por aquelas terras professada (Mello e Souza, 2006, p.67). Contudo, é certo que o acordo que a Coroa de Portugal estabeleceu com o Reino do Congo pode ter proporcionado o êxito às missões católicas nas regiões central e sul do continente africano. Passados os primeiros impactos do encontro entre portugueses e congoleses, a conversão estratégica do Mani Congo Nkuwu Nzinga (João I do Congo), de seu filho Nzinga a Mbemba (Afonso I) e de alguns chefes locais no ano de 1491 atuaria como propaganda incentivadora do catolicismo nessa parcela da população africana. Tendo a igreja de pedra erguida em poucos meses como cenário em apresentações para o povo, a elite do Congo com o passar do tempo também se mostraria partícipe da nova religião (Meredith, 2017, p.120), ratificando a oficialidade do catolicismo nessas terras, ainda que se tratasse de uma prática que depois seria inculturada à religião tradicional banta. Posteriormente esse apoio da corte congolesa seria fundamental para a conquista de outros territórios, como Moçambique e Angola, favorecendo a passagem dos missionários e instaurando outras rotas de propagação da nova religião no continente, fundando dessa maneira novos territórios católicos na África do século XVI.

Do ponto de vista das interferências territoriais, nos povoados bantos, aqueles localizados em pontos de maior circulação de estrangeiros, seriam erguidos templos católicos como marcos da presença colonizadora, caso da igreja de 1628 consagrada a Nossa Senhora do Rosário em Luanda (Fonseca, 2016, p.70). Para animar a prática religiosa dos africanos ao redor desses edifícios, também seriam instauradas irmandades leigas dedicadas especialmente à devoção ao rosário, sendo identificadas uma no ano de 1577 na cidade de Sena, Moçambique, outra na Igreja de São Salvador datada 1610, em Luanda, Angola (Karasch, 
2018, p.433), e uma última localizada na Igreja do Rosário nessa mesma cidade, fundada em 1628 (Fonseca, 2016, p.70). Nas regiões rurais mais remotas, um modelo territorial mais incisivo teria sido implementado pelos capuchinhos (Thornton, 1984, p.151), organizando esses lugares a partir de aldeamentos onde a capela assumiria papel de destaque, imprimindo, dessa maneira, uma nova concepção espacial que restringiria o convívio dos africanos aos padrões sociais reconhecidos pelo catolicismo (Figura 1).

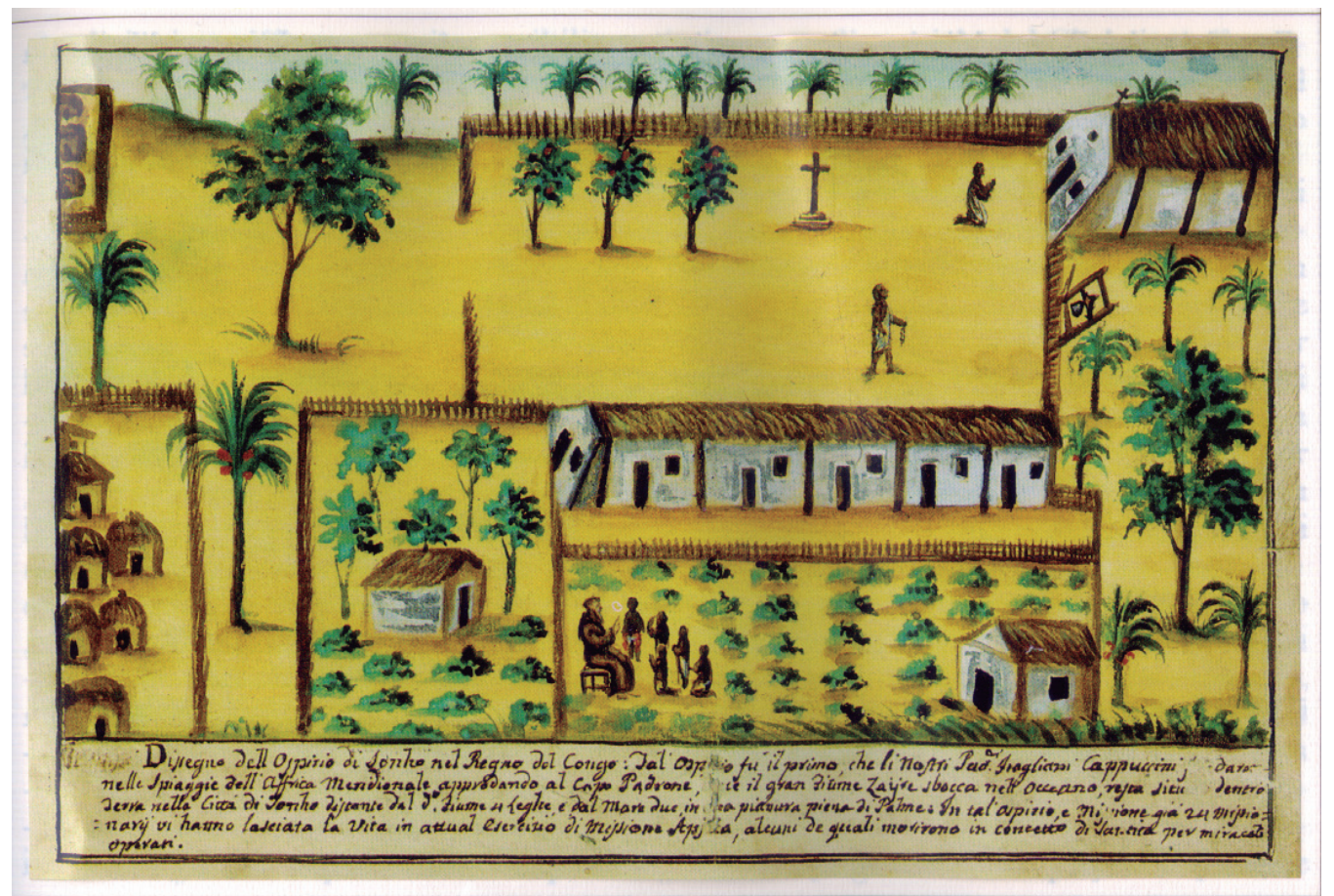

Figura l - "Hospício de Sonho", no Congo. Assentamento dos capuchinhos com igreja, casas para os evangelizados e pomar. Reprodução de aquarela atribuído a Bernardino Ignazio, 1747 (Collo; Benso, 1986, p.65).

No Congo, o catolicismo sob os desígnios da Coroa Portuguesa entraria em xeque nas primeiras décadas do século XVII, quando ambos os reinados divergiram em seus interesses particulares. A transferência da diocese de São Salvador da capital congolesa para Luanda, além de reafirmar o poder de Portugal sobre o reino africano, prejudicou consideravelmente o desenvolvimento do catolicismo nesse lugar por causa da redução considerável de padres. Em contrapartida ao contexto político que ocasionava um panorama desafiador para a Igreja congolesa nas regiões centrais, o catolicismo praticado no meio rural estaria preservado em suas particularidades. Nesses locais a evangelização se daria a partir de pequenos núcleos, organizados com o fim único da prática de um cristianismo profundamente inculturado, puramente africano, onde o protagonismo seria exclusivamente dos negros leigos, mestres no trabalho evangelizador e por vezes educadores da língua portuguesa. Esse quadro, que fora observado 
até o final do século XVIII conforme relatos de viajantes (Thornton, 1984, p.165), pode ter inspirado as práticas católicas do povo negro na diáspora, especialmente os que se dirigiram para lugares em que a liberdade religiosa estaria assegurada igualmente pela escassez de padres.

Não há dados precisos quanto ao número de africanos que chegaram nas colônias americanas já convertidos ao catolicismo; contudo, é certo que o trabalho dos missionários faria que conhecessem as práticas cristãs antes mesmo de cruzar o Atlântico. No Brasil, o uso estratégico do negro como catequista no ambiente rural (Beozzo, 1980, p.273), a instauração de irmandades católicas negras em contexto urbano ${ }^{6}$ e as migrações forçadas impostas pelo comércio escravista interno ocasionariam a difusão de um catolicismo negro por todo o país, circulando por várias cidades e estando presente inclusive em espaços mais remotos como o dos quilombos (Vieira, 2016, p.67). Como fizeram na cidade de São Paulo, sob a proteção de seus santos de devoção, os malungos organizariam seu patrimônio, estabeleceriam suas redes de sociabilidade e lutariam pela preservação dos territórios conquistados.

\section{Africanos em solo brasileiro}

A presença de negros no Brasil foi notada já na primeira metade do século XVI, momento em que seriam introduzidos como escravizados em atenção a necessidades da temporalidade da cana-de-açúcar. Nos engenhos, espalhados pelo litoral do Nordeste àquela época, a condição de servil imposta negligenciaria uma identificação mais específica a esses africanos, denominando "negros da Guiné" a todos esses imigrantes, independentemente de suas línguas ou credos. Contudo, ainda que a condição de escravos generalizasse a todos os negros sob a mesma alcunha, algumas características identitárias facilitariam a distinção das diferentes etnias, em especial a daqueles habitantes das colônias portuguesas, destacando os bantos reconhecidos pelo idioma e identificados pelo interesse devocional -, nas histórias que os padres jesuítas narraram sobre o exercício catequético oferecido a indígenas e negros nos primeiros anos da colonização do Brasil (Leite, 2004, p.334).

No século XVII, as dificuldades do uso do indígena como da mão de obra e a escassez dos "escravos da Guiné" promoveriam um outro ciclo de imigração forçada, estimulando o ingresso de grande quantidade de "negros de Angola", e instaurando uma nova rota transatlântica que abasteceria as colônias americanas nos anos que seguiram o comércio escravista. A presença numerosa dos bantos também seria distinguida no tratamento entre senhores e escravos, na habilidade desses no serviço doméstico (Vianna Filho, 2008, p.82) e na assimilação do catolicismo. No âmbito religioso, a prática ancestral banta, segundo alguns autores, ${ }^{7}$ para além de favorecer a inserção nas práticas cristãs, justificaria inclusive uma suposta flexibilidade quando comparada aos "negros da Guiné" ou "escravizados iorubás", beneficiando, por um lado, as relações estabelecidas pelo regime de escravidão e intensificando, por outro, a circulação desses grupos de negros no contexto urbano colonial. 
As temporalidades econômicas no Brasil colonial, cujo êxito se deveu à participação da mão de obra africana, distribuiriam os grupos étnicos desigualmente em solo brasileiro, concentrando determinadas etnias de povos negros de acordo com as suas expertises nas localidades mais importantes. Nas outras cidades, alheias aos ciclos econômicos, a presença negra estaria restrita a estratégias de subsistência do lugar, estando esses números limitados a quantidade de escravos que a classe dominante poderia adquirir. Não obstante o valor agregado à mão de obra negra, cabe ressaltar que, em algumas regiões, a permanência do uso de indígenas como escravos poderia interferir no contingente de africanos escravizados, estabelecendo uma outra atividade comercial rentável, que motivaria inclusive conflitos entre colonos e religiosos como por exemplo aconteceu na província de São Paulo.

No caso particular da cidade de São Paulo, embora a fundação sobre um platô tenha favorecido o clima e a defesa de seus habitantes, o distanciamento da costa litorânea e das sedes do governo-geral selaria o destino econômico desse lugar por muito tempo, contribuindo de forma incisiva na quantidade de negros que ocupavam o plano urbano paulista. Ainda que os aspectos naturais tenham favorecido algum tipo de atividade agrícola ou pastoril, as condicionantes da localização territorial impediriam um comércio ativo, restringindo o número e a especificidade dos africanos escravizados. A instabilidade da economia paulista nos dois primeiros séculos de fundação faria a escravidão indígena mais recorrente em relação a dos africanos, limitando o emprego da mão de obra negra às atividades de agricultura, construção civil e serviços domésticos, atendendo exclusivamente a necessidades da elite, civil e clerical, pelo elevado custo dessa categoria de escravizados (Silva, 2008, p.117).

A agricultura se manteve como a principal atividade econômica paulista ao longo do século XVIII, e por meio dela um importante número de negros passaria a circular por São Paulo, em decorrência do fim da escravidão indígena (1758) e do desenvolvimento da exploração de ouro e diamantes nas Minas Gerais. Ainda que alguns poucos indígenas se mantivessem na condição de escravos, a dinâmica da província e a melhora econômica que São Paulo apresentara na segunda metade dos Setecentos impulsionariam o ingresso de negros escravizados, acentuando gradualmente a inserção desses na cidade em um processo que só se concluiria com a temporalidade do café no século XIX.

\section{São Paulo e os territórios malungos}

A cidade de São Paulo dos Oitocentos, em seu desenho urbano, preservaria as características das demais cidades fundadas em tempos em que a Igreja Católica impunha seu poder sobre a conformação dos aglomerados humanos e dos espaços públicos. A Coroa de Portugal delegava à Mitra o desenvolvimento espacial das vilas e cidades, que, por sua vez, além da orientação e escolha de terrenos para implantação das edificações religiosas, estabelecendo os limites territoriais das igrejas ou a abrangência de seus adros, também detinha o controle so- 
bre as formas de ocupação, ditando os critérios na concessão de um terreno para um determinado grupo social e programando o uso dos demais espaços urbanos a partir de seus interesses (Marx, 1989, p.32). No traçado urbano de São Paulo, além da destacada verticalidade dos templos católicos, o poder da Igreja ainda seria refletido horizontalmente no mapa da cidade, oferecendo aos habitantes uma experiência social em ruas circunscritas num "triângulo religioso", cujos vértices seriam os edifícios dos beneditinos, dos carmelitas e dos franciscanos. $\mathrm{O}$ número considerável de igrejas e capelas que despontavam na paisagem paulistana despertaria a atenção de Saint Hilaire e de outros viajantes, ${ }^{8}$ assim como as demonstrações de fé pública do povo de São Paulo nas procissões solenes que circulavam pelas principais ruas da cidade, permitindo que todos os habitantes tivessem contato com a religião oficial (Martins, 2003, p.425). Contudo, o catolicismo paulista encontraria espaço para reafirmar o papel que o negro teria naquele cenário, restringindo a circulação desses aos lugares condicionados a todos de sua cor.

Em concordância com a vontade eclesiástica, a cidade de São Paulo, em 1802, ofereceria aos negros, escravizados ou livres, a opção por quatro irmandades católicas exclusivamente negras, duas dentro dos limites do triângulo religioso - a Irmandade de Nossa Senhora do Rosário dos Homens Pretos de 1711 (Figura 2) e a outra Irmandade de São Benedito de meados do século XVIII - , uma ereta na paróquia de Santa Efigênia - Irmandade de Santa Efigênia e Santo Elesbão de 1758 - e outra na de Nossa Senhora da Penha - Irmandade de Nossa Senhora do Rosário dos Homens Pretos da Penha de França de c. 1755 - que, ainda que distantes, mantinham relações próximas com a vida social e religiosa do planalto de Piratininga pela jurisdição eclesiástica da Sé.

O cenário paulista oficialmente católico, contudo, não seria impedimento para a população negra praticar seus rituais ancestrais de maneira estratégica em zonas da cidade de São Paulo. Considerado à época como feitiçaria, o exercício da religião africana teria sua difusão principal no comércio paulista, praticado por mulheres negras iorubás que vendiam objetos mágicos afrolitúrgicos no Beco das Minas - denominado Rua do Quartel no século XIX - e por homens africanos que especificavam ervas e compartilhavam receitas sagradas no Mercado de São João, localizado na baixa da ladeira de mesmo nome (Rolnik, 1997, p.61). Já nas proximidades das igrejas, esses mesmos negros não católicos poderiam se agrupar diante da Igreja da Misericórdia, onde, desde 1793, haveria um chafariz obra do arquiteto Tebas, o negro Joaquim Pinto de Oliveira; na Capela dos Aflitos, localizada dentro de um cemitério de mesmo nome consagrado em $1779,{ }^{9}$ onde negros de todos os credos teriam um campo santo para cumprir seus rituais fúnebres; e na sacristia da Igreja de Nossa Senhora dos Remédios (Figura 3), utilizada como sede do movimento abolicionista dos Caifazes desde 1877 (Quintão, 2002, p.80), sugerindo que a concentração dos negros ao redor das igrejas paulistas nem sempre seria pela anuência cristã. 


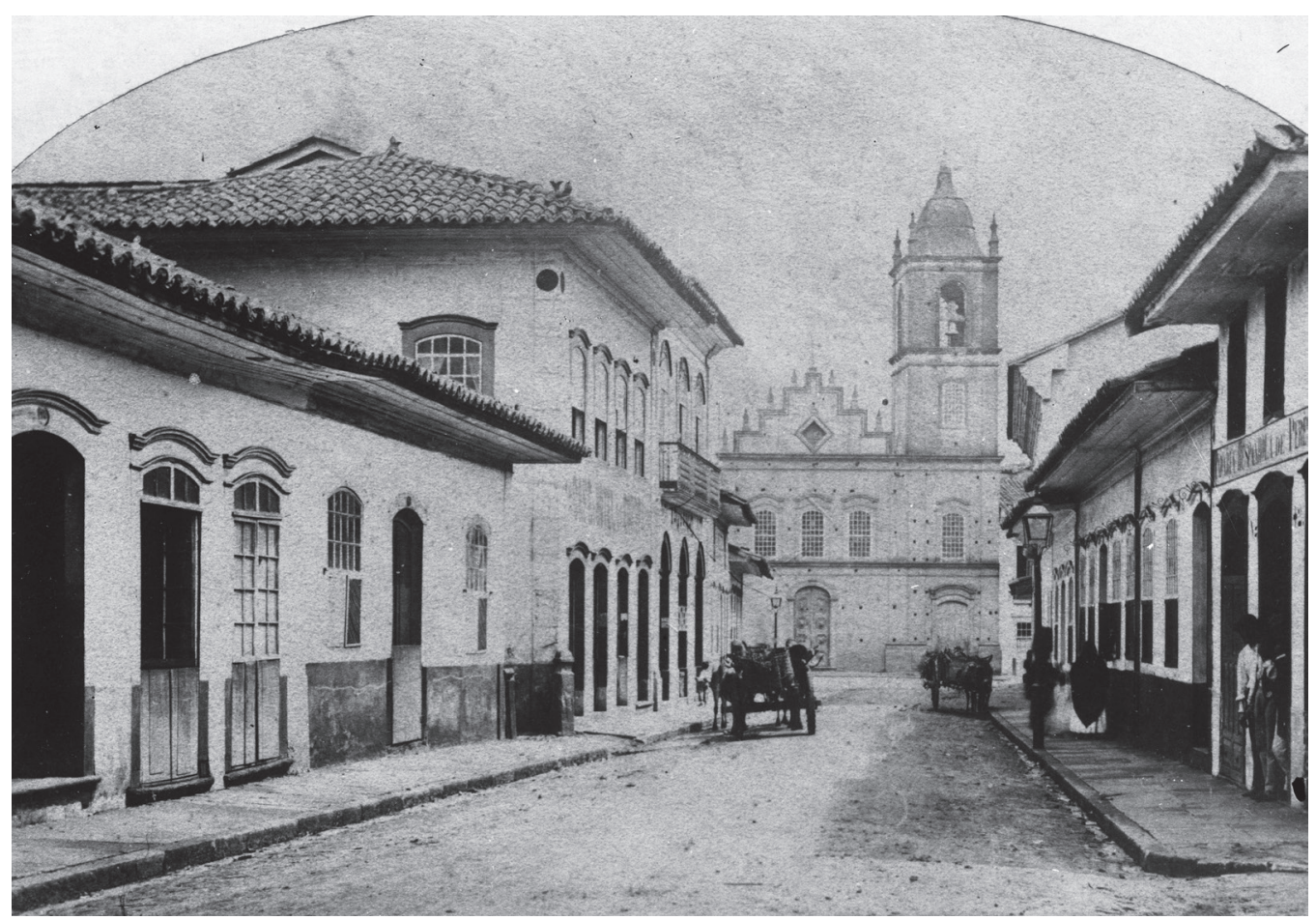

Figura 2 - Igreja de Nossa Senhora Rosário dos Homens Pretos. 1860-1870. Militão Augusto de Azevedo. Acervo Fotográfico do Museu da Cidade de São Paulo.

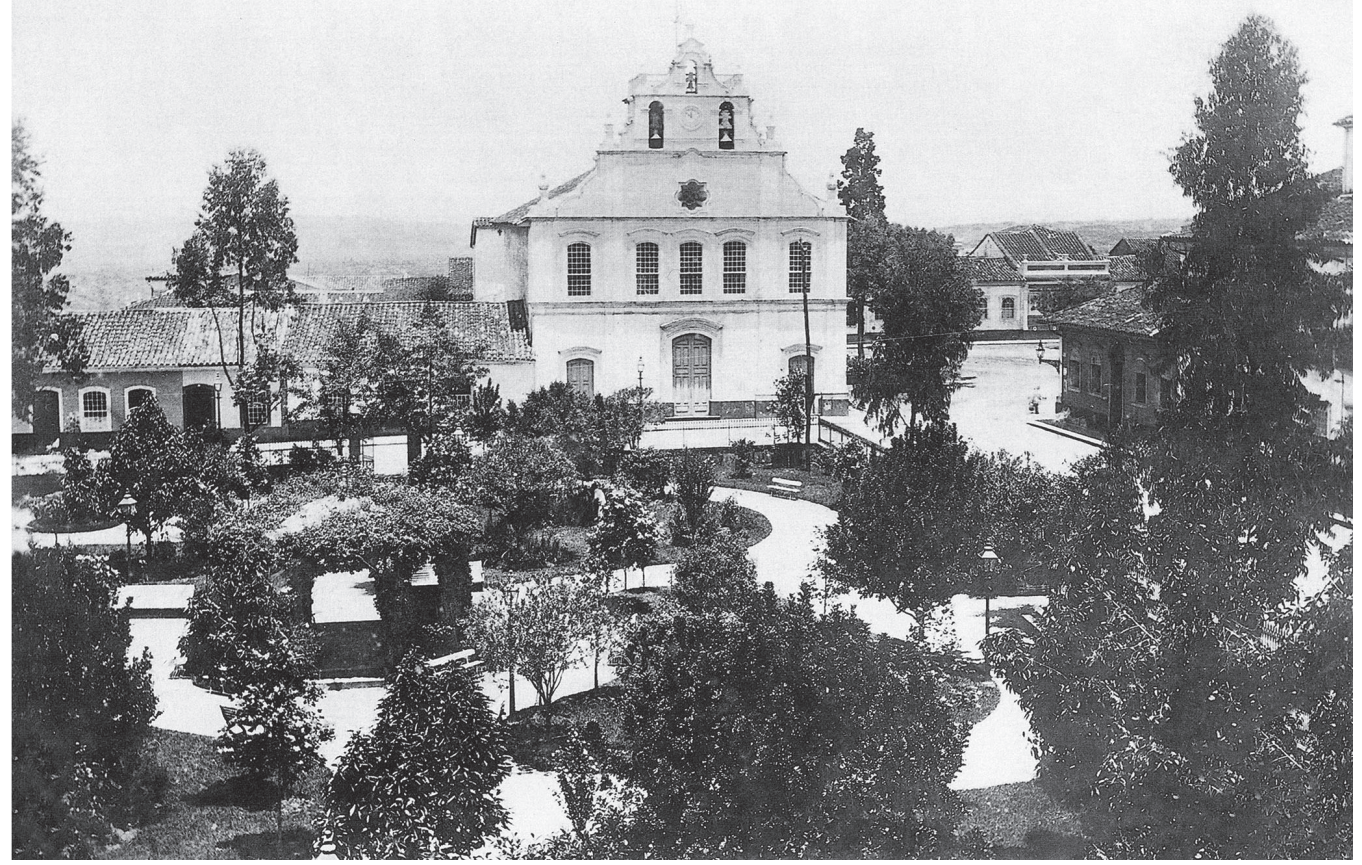

Figura 3 - Igreja de Nossa Senhora dos Remédios. c. 1877. Militão Augusto de Azevedo. Álbum Comparativo da Cidade de São Paulo 1862 - 1887 - 1914. Foto n.061. Disponível em: <http://www.hagopgaragem.com/saopaulo/ sp_comparativo/sp_compa_061.jpg >. 
Não obstante o teor de conversão ao catolicismo, os negros compreenderam que a adesão a irmandades católicas garantiria alguns privilégios, permitindo o resgate de algumas tradições ancestrais - como danças africanas e ritos fúnebres -, a formação de redes de sociabilidade e a constituição de algum patrimônio, como acontecera com os irmãos da mais antiga Irmandade do Rosário dos Pretos paulista. Contudo, para essa irmandade particular, ao menos no documento público do Compromisso datado de 1778, o exercício de outras práticas religiosas não era algo aceito, ${ }^{10}$ havendo predileção por um catolicismo mais genuíno, praticado especialmente pelos bantos, grupo etnolinguístico presente nos territórios católicos de São Paulo desde os setecentos. Nessa irmandade negra paulista, entre os adeptos, haveria predominância dessa etnia africana, favorecendo posições de destaque como os cargos de Rei e Rainha, assegurados aos procedentes de Angola no século XVIII, ${ }^{11}$ e transferidos aos consanguíneos do Congo no século XIX (Quintão, 2002, p.40).

Com edificação datada de 1725 , há hipóteses de que a relevância do lugar de implantação da igreja - localizada no alto da antiga ladeira do Açu, posterior ladeira de São João - seja resultante da interferência dos beneditinos, haja vista que possivelmente a instituição da irmandade tenha sido iniciativa dos escravizados que trabalhavam para essa ordem monástica (Camargo, 1953, p.70). O lugar, que à época da fundação preservaria as características de um subúrbio (Quintão, 2002, p.62), seria valorizado com o decorrer dos anos, influenciando consideravelmente na arquitetura da Igreja do Rosário dos Pretos e no urbanismo do seu entorno. Embora conservado o seu sistema construtivo de taipa de pilão, o templo teria os elementos decorativos da fachada atualizados no decorrer do século XIX (Figura 4), preservando os grandes volumes da nave e da torre, copiosos na observação de Visconde de Taunay em comparação a vizinha Igreja de São Bento (Bruno, 1981, p.82). Quanto ao Largo do Rosário, a valorização do espaço, em contrapartida, implicaria expropriação do terreno do cemitério dos pretos que estaria contíguo ao templo no ano de 1872 (Martins, 2003 , p.325), na demolição de casas que compunham os bens imóveis que eram patrimônio da Irmandade para o novo alinhamento da rua no ano de $1861,{ }^{12}$ na tomada de parte do calçamento a frente da Igreja para ajuste da linha de bonde em $1879^{13}$ e na remoção do chafariz do Rosário no ano de $1887 . .^{14}$

A Irmandade de São Benedito, por sua vez, não chegaria a edificar um templo para a devoção dos malungos, mas se aproveitaria da crise instaurada entre as ordens religiosas e o governo imperial para expropriar a principal igreja dos franciscanos em São Paulo (Figura 5). Organizada em meados do século XVIII por iniciativa dos frades para as práticas católicas de seus escravizados, o crescimento da devoção, acolhendo também os negros libertos no início dos Oitocentos (Quintão, 2002, p.45), animaria a construção de uma capela própria fora do convento, no lado esquerdo do cruzeiro do Largo de São Francisco (Rower, 1941, p.118). Contudo, como os irmãos não queriam ficar sob a jurisdição do bispado de São Paulo, ficou acertado o uso da Igreja de São Francisco, colocando 


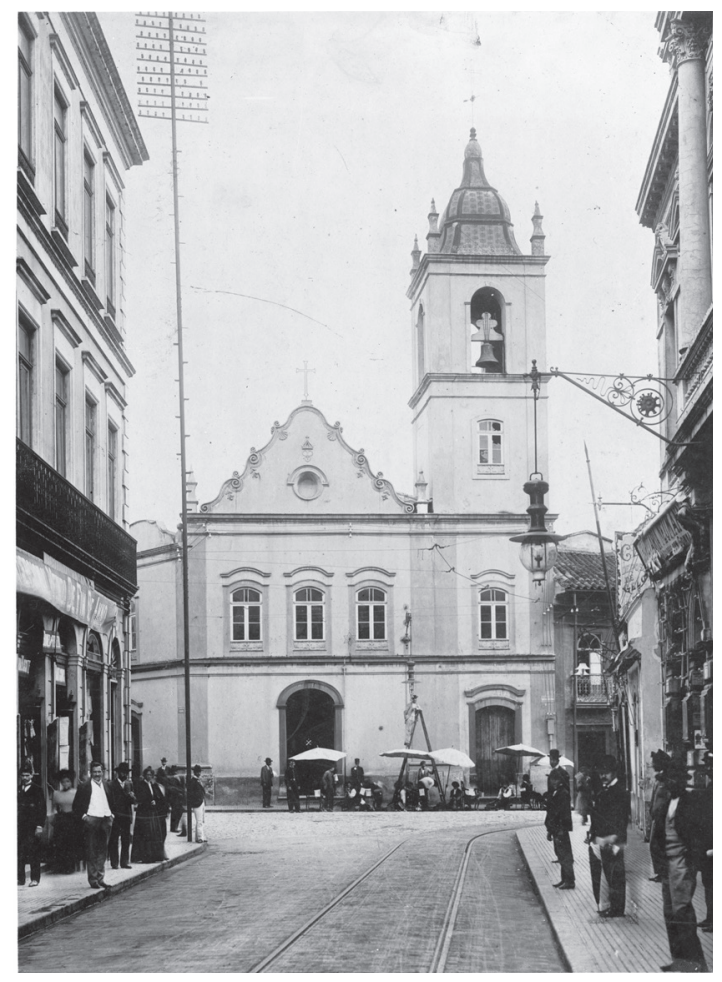

Figura 4 - Rua XV de Novembro com Igreja de N. S. do Rosário dos Homens Pretos. 1904. Autor Desconhecido. Acervo Fotográfico do Museu da Cidade de São Paulo.

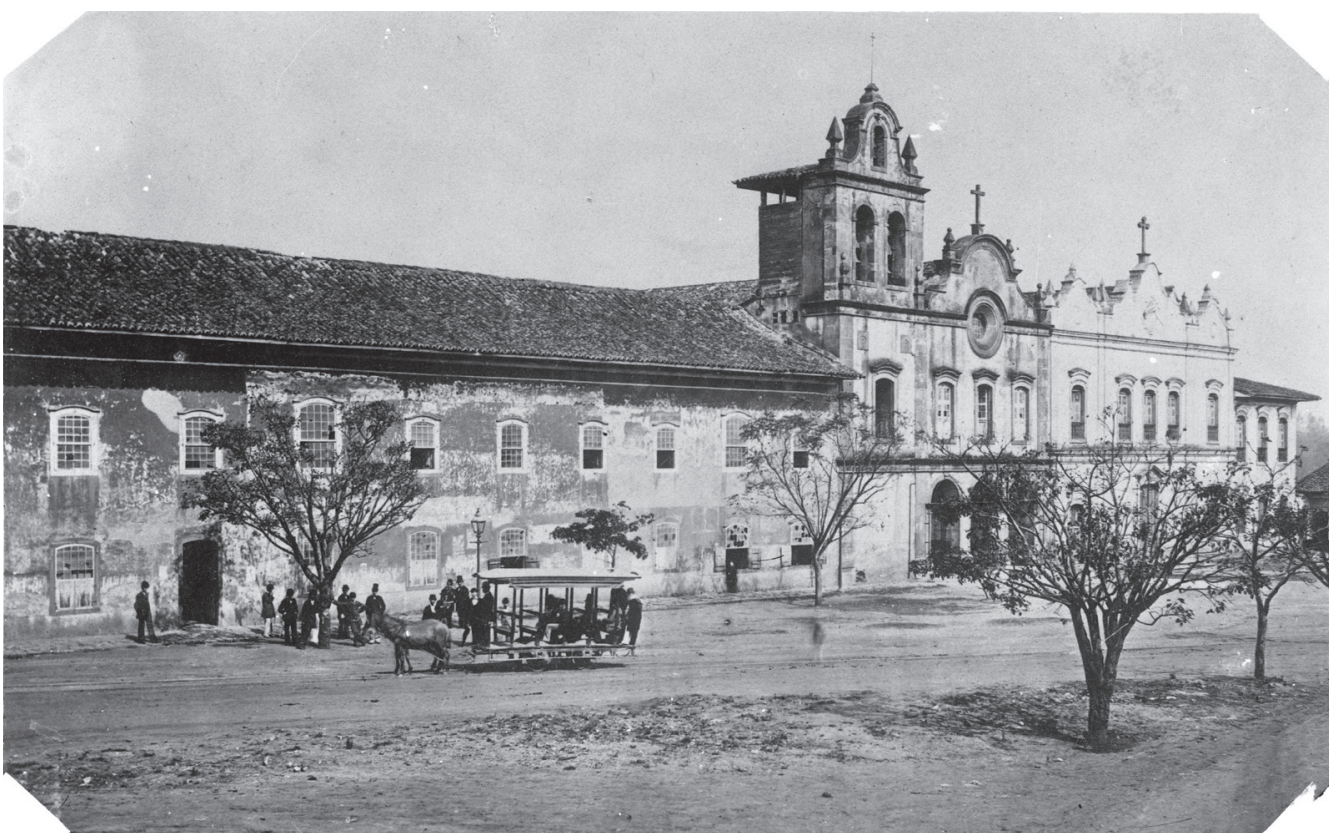

Figura 5 - Convento de São Francisco, Igreja de São Francisco e Igreja da Ordem Terceira do Pai Seráfico. 1874. Militão Augusto de Azevedo. Acervo Fotográfico do Museu da Cidade de São Paulo. 
São Benedito ao lado de Santo Antônio no altar principal. Posteriormente, com a saída dos franciscanos em meados do século XIX, a irmandade negra assumiria a responsabilidade desse templo, alterando o nome para Igreja de São Benedito, estabelecendo relações com outras irmandades e configurando-se como um importante território do catolicismo negro paulista nos oitocentos. O retorno dos frades no ano de 1891 daria início ao processo de retomada do templo pelos religiosos, uma década de disputas territoriais com os devotos de São Benedito que culminara com a retirada da imagem do santo negro do altar-mor e a destituição da irmandade nos primeiros anos do século XX (Rower, 1941, p.119).

Embora instalada em edificação à parte do "triângulo religioso paulista", a Irmandade de Santa Efigênia e Santo Elesbão de São Paulo teve a fundação intimamente ligada aos Irmãos do Rosário, uma vez que sua instituição em 1758 se deu em atenção aos anseios desses pela veneração dos santos africanos (Quintão, 2002, p.89). Em 1801 a irmandade transladaria suas imagens para o novo templo, passando a ocupar a Capela de Nossa Senhora da Conceição erguida no século XVIII em terras além Rio Anhangabaú, acessadas pela Ponte do Açu - posteriormente chamada de Ponte de São João. A criação da freguesia de Santa Efigênia em 1809 proporcionaria o aumento do número de devotos, corroborando para a irmandade negra organizar um importante patrimônio composto de terrenos e casas que seriam alugadas, além dos objetos litúrgicos apresentados com brio nas procissões realizadas pela Sé paulista e nos seus festejos particulares em honra aos padroeiros. Contudo, ainda com tais possibilidades de investimentos, as obras da igreja de Santa Efigênia (Figura 6) teriam sido finalizadas somente em $1863^{15}$ e o prédio, bem constituído, seria o estopim da desavença entre os malungos e o vigário José de Camargo Barros, especialmente as dependências usadas pela Irmandade em suas reuniões, expropriadas pelo sacerdote no ano 1888 após longos meses de discussão. Em 1890 a disputa territorial teria como desfecho a transmissão da posse de todo o patrimônio para o bispado paulista e a dissolução da Irmandade. Como ato de repúdio da Irmandade de Santa Efigênia e Santo Elesbão, ante a impossibilidade do exercício religioso na igreja construída por iniciativa e esforços próprios, o mesmo vigário narraria que, nos primeiros dias de maio de 1890, as imagens de santos padroeiros teriam sido levadas pelos irmãos para a Igreja de São Benedito; de lá elas nunca mais retornariam. ${ }^{16}$

Longe da região mais central da cidade de São Paulo, os negros da freguesia de Nossa Senhora da Penha de França também receberiam permissão para erigir um templo em devoção a Nossa Senhora do Rosário no ano de 1802. ${ }^{17}$ Organizados desde 1755 , a proximidade com as terras ocupadas pelos indígenas guaianás favoreceria relações entre ambos os escravizados, resultando na adesão dos indígenas ${ }^{18}$ nessa que era uma irmandade católica organizada por negros (Almeida, 2019, p.40). O templo, erguido de costas para a igreja matriz utilizada pelos brancos, levaria anos até sua finalização em razão dos poucos recursos desses malungos, sendo concluído provavelmente no final do século XIX a partir 


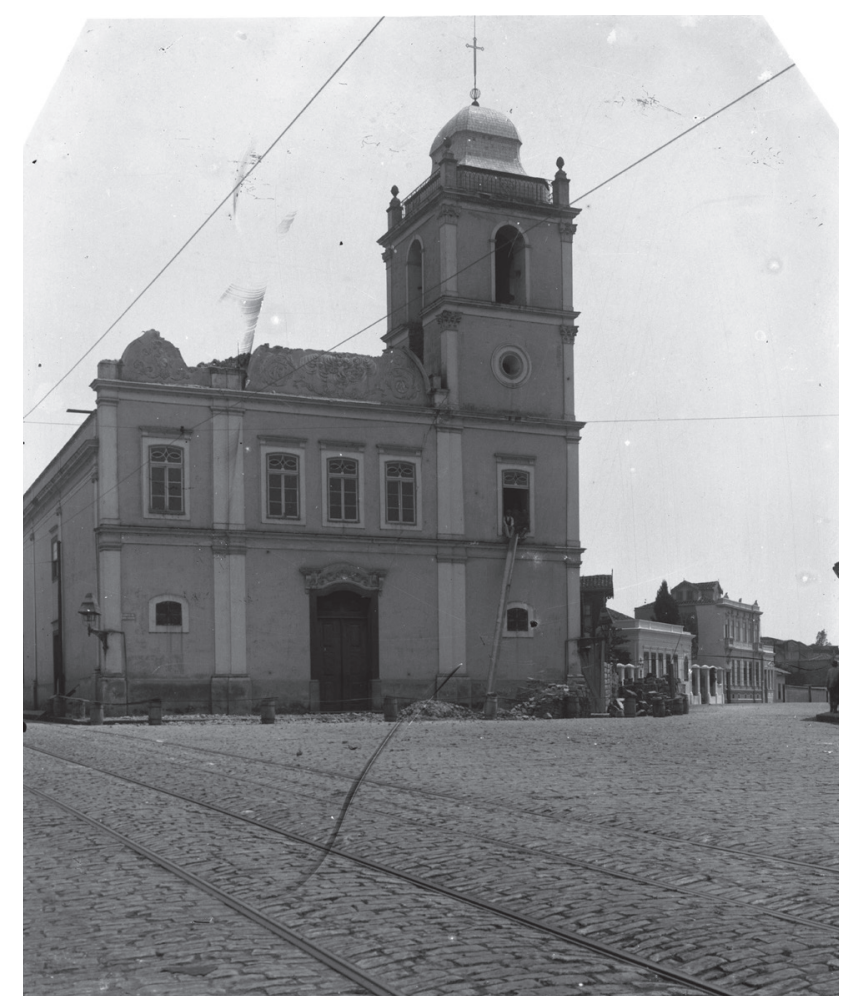

Figura 6 - Igreja de Santa Efigênia com o frontão em processo de demolição. c. 1905. Autor Desconhecido. Acervo Fotográfico do Museu da Cidade de São Paulo.

das relações entre esses e os demais negros católicos que habitavam São Paulo. Nas primeiras décadas do século XX, com a chegada dos padres redentoristas, a edificação sofreria atualizações decorativas na fachada principal (Figura 7) e adaptações em seu interior. A intervenção desses religiosos também acometeria a autoridade dos malungos sobre o patrimônio centenário construído, o que resultaria na diminuição dos irmãos e na dissolução da Irmandade nas primeiras décadas do século XX, restando aos malungos apenas a mais antiga Irmandade do Rosário para suas práticas católicas.

\section{Considerações finais}

Embora imerso no regime escravocrata, o século XIX permitiria a expansão dos territórios católicos negros em São Paulo, instaurando rotas de circulação que configurariam a gênese da presença negra no plano urbano paulista. A dissolução das irmandades dos malungos, resultante da batalha pela preservação de um legado material e imaterial religioso, implicariam a destruição de importantes edificações e na migração forçada dos devotos em busca de abrigo na Igreja do Rosário dos Homens Pretos da cidade de São Paulo, que ainda era preservada em sua integridade física no início do século XX. Contudo, ainda com os protestos dos negros católicos, o novo contexto urbano do "triângulo histórico paulista” seria implacável com a Igreja de Nossa Senhora do Rosário dos Ho- 


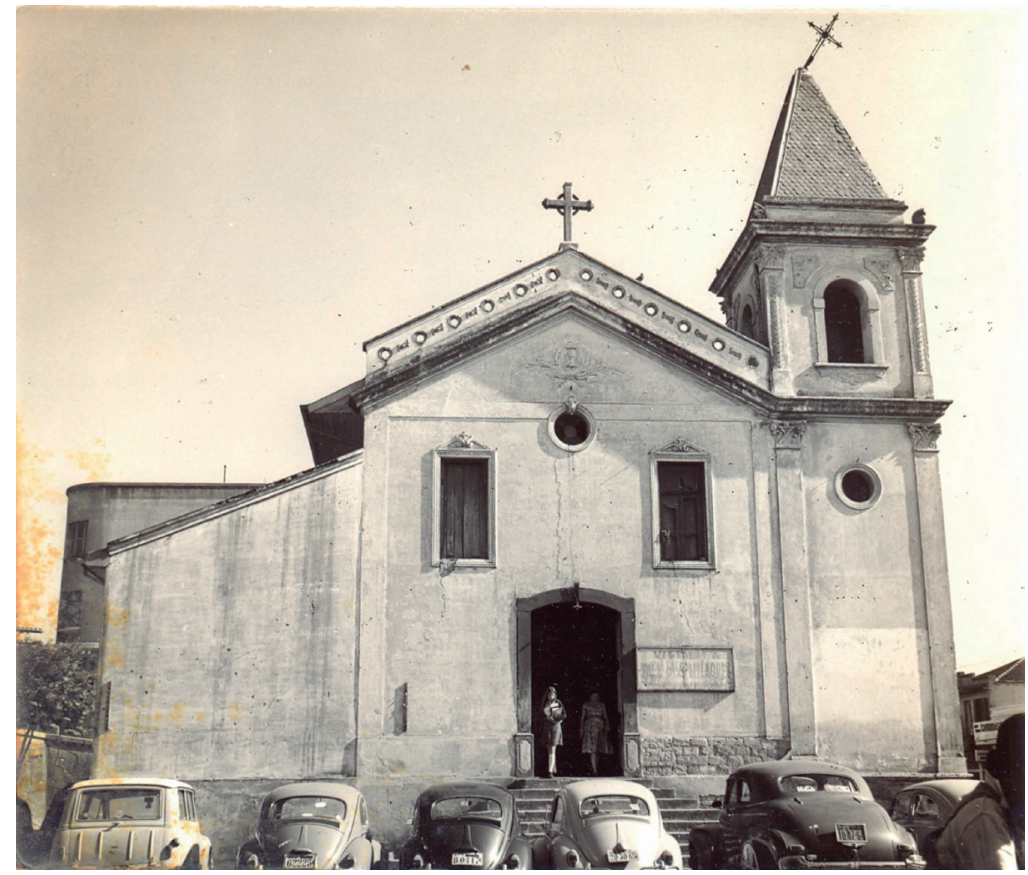

Figura 7 - Igreja de Nossa Senhora do Rosário dos Homens Pretos da Penha de França. 1968. Autor Desconhecido. Acervo Movimento Cultural da Penha.

mens Pretos, destruindo o templo e revelando, para além dos alicerces que sustentavam as paredes em taipa, a intolerância inerente à classe dominante, que se apropriava da arquitetura e do urbanismo para cercear o direito dos negros à cidade, refutando a impossibilidade do controle físico dos ex-escravizados nos anos pós-abolição.

No aspecto arquitetônico, os projetos dos novos templos a partir de tipologias sugeridas pela Igreja em processo de romanização - o ecletismo para a Igreja do Rosário e o neorromânico para a Igreja de Santa Efigênia -, e no caráter urbano, a substituição do nome simbólico das ruas ou espaços públicos desses territórios por nomes que atendiam os interesses da classe dominante - caso da substituição do Largo do Rosário por Praça Antônio Prado -, seriam medidas que reforçariam o interesse da elite em desvincular as edificações religiosas dos negros protagonistas de suas histórias. As novas igrejas poderiam contemplar nichos para a exposição dos antigos oragos ou mesmo a permanência do nome do padroeiro no título do templo, contudo o novo momento da Igreja Católica e as diretrizes impostas à cidade pela classe dominante paulistana impossibilitariam o retorno dos malungos a determinados lugares. Na São Paulo do século XX, as práticas do Catolicismo Negro encontrariam lugar nas regiões mais periféricas, possibilitando a fundação de novas igrejas no entorno de onde, aquele momento, se aglomeravam os descendentes dos escravizados. Aos territórios dos malungos, silenciados na memória urbana paulista, restaria a salvaguarda na cartografia e na iconografia oitocentista. 


\section{Notas}

l Termo utilizado pelos negros bantos para designar outro africano afiliado a irmandade católica.

2 Por concessão da bula Inter Coetera, o papa Alexandre VI concederia a Ordem de Christo, principal financiadora das navegações portuguesas, o domínio espiritual sobre as novas terras descobertas, cabendo a esta instituição o desenvolvimento de estratégias e a implantação dos equipamentos necessários a expansão do catolicismo, como igrejas e casas religiosas. Esse domínio recairia sobre a Coroa de Portugal a partir do século XVI (Fonseca, 2016, p.69).

3 Na cidade de São Tomé, parte do Arquipélago de São Tomé e Príncipe, dentre os elementos urbanos que contribuíram para o povoamento desse lugar estão as Igrejas de Santa Maria e São Francisco (incluídas ao mosteiro de mesmo nome, com obras iniciadas a partir de 1493) e a igreja Matriz de Nossa Senhora da Graça (construída em 1500) (Silva, 2012, p.53). Na cidade de Santo Antônio, também do mesmo arquipélago, foram fundadas a Igreja de Nossa Senhora da Conceição (entre 1495 e 1521), a Igreja de São João Batista (1562), a capela do Bom Despacho (1617), a capela de São Sebastião (c. séc. XVI) e a Igreja do Hospital da Misericórdia (Fernandes, 2012, p.73). Na Ribeira Grande, ilha de Santiago no Cabo Verde, em 1466 quando da chegada dos freis capuchinhos, já existia um templo católico que posteriormente fora dedicado a devoção ao Espírito Santo. Contudo, o mesmo arquipélago ainda contava com as igrejas de São Filipe (1480) e de Nossa Senhora do Rosário (1495), esta última ainda existente e considerada um dos templos católicos mais antigos da África. Disponível em: <http://diocesesantiago.org/site/index.php/diocese/historia>. Acesso em: 26 mar. 2020.

$4 \mathrm{Em} 1573$ seria fundado o convento dos agostinianos nas proximidades do Castelo de São Jorge, sendo essa a edificação católica mais antiga de Gana (Moreira, 1989, p.52).

5 A pesquisa de Marianno Carneiro Cunha (1985), no livro Da Senzala ao Sobrado: arquitetura brasileira na Nigéria e na República Popular do Benin, aponta que, no aspecto da territorialidade, somente em meados do século XIX, com o retorno dos negros que estiveram no Brasil, é que o plano urbano de algumas cidades da região dos iorubás passaria a dar relevância ao lugar das igrejas, conformando possíveis territórios cristãos a partir do agrupamento destes negros católicos.

6 Há notícias de uma irmandade negra brasileira já em 1552. Contudo, oficialmente, a instituição da primeira seria no ano de 1586, organizada pelos padres jesuítas para devoção a Nossa Senhora do Rosário em Pernambuco (Almeida, 2019, p.10).

7 Pedro Calmon (1935), Hermann Watjen (1938), Luiz Vianna Filho (1946), Eduardo Hoonaerth (1991), Marina de Mello e Souza (2002).

8 Além de Saint Hilaire que percorreu a cidade em 1819, mencionaram tais informações John Mawe, em visita no ano de1808, Gustavo Beyer, de passagem pela província em junho de 1813, Daniel Parish Kidder, que visitou em janeiro de 1839, e Carl Von Koseritz, que esteve em São Paulo no ano de 1883 (Bruno, 1981).

9 Livro de Patrimônio - 001 Ereção - 1746-1864. Cota 01.02.008, p. 179. Arquivo da Cúria Metropolitana de São Paulo (ACMSP).

10 Capítulo VIII: “O Procurador terá cuidado [... ] saber se ha algun Irmão, ou Irma, que uze de ervas, ou feitiçarias, e havendo estes taes, serão logo expulsos da Irmandade 
sem demissão alguma." Compromisso da Irmandade de Nossa Senhora do Rosário dos Homens Pretos de São Paulo. 11 de julho de 1778 (ACMSP).

11 Capítulo XXII: "Nesta Santa Irmandade se farão todos os annos hum Rey e huma Raynha os quaes serão de Angolla, e serão de bom procedimento[...]” (ibidem).

12 Anais da Câmara Municipal, $0^{\text {a }}$ Sessão realizada em 28.11.1861, p.223. Centro de Memória da Câmara Municipal de São Paulo (CMCMSP).

13 Anais da Câmara Municipal, Sessão Ordinária realizada em 18.9.1879, p.129 (CMCMSP).

14 Anais da Câmara Municipal, $3^{\text {a }}$ Sessão Ordinária realizada em 13.1.1887, p.17 (CMCMSP).

15 Livro do Tombo da Paroqchia de Santa Ephigenia. 1887-1904. Cota 19-2-2, p.2 (ACMSP).

16 Ibidem, p.20.

17 Livro de patrimônio 002. Cota 01.02.003, p.214 (ACMSP).

18 Reconhecidos como "súditos" no Livro de Assentamento da Irmandade de Nossa Senhora do Rosário dos Homens Pretos da Penha de França. 1755-1880, conservado no Arquivo Diocesano de São Miguel Paulista (ADSMP).

\section{Referências}

ALMEIDA, P. F. de. Contribuições para a história do protagonismo de negros e indios na Irmandade de Nossa Senhora do Rosário dos Pretos da Penha de França. Coord. Patrícia Freire de Almeida; pesquisa Antônia Aparecida Quintão; transcrição paleográfica Judie Kristie Pimenta Abrahim. São Paulo: Movimento Cultural Penha, 2019.

BEOZZO, J. O. História da Igreja no Brasil Segunda Época. In: BEOZZO, J. O. (Org.) História Geral da Igreja na América Latina. Petrópolis: Vozes, 1980. t.II/2.

BRUNO, E. S. Memória da Cidade de São Paulo: Depoimentos de Moradores e Visitantes /1553-1958. Registros 4. Prefeitura Municipal de São Paulo, Secretaria Municipal de Cultura. São Paulo: Publicação do Departamento do Patrimônio Histórico, 1981.

CAMArgo, P. F. da S. (Mons.) A Igreja na História de São Paulo (1676-1745). São Paulo: Instituto Paulista de História e Arte Religiosa, 1953. v.3.

COLlO, P.; BENSO, P. (Ed.) Sogno: Bamba, Pemba, Ovando e altre contrade dei regni di Congo, Angola e adjacenti. Milano: Publicação particular de Franco Maria Ricci, 1986.

CUNHA, M. C. da. Da Senzala ao Sobrado: arquitetura brasileira na Nigéria e na República Popular do Benim. São Paulo: Nobel; Edusp, 1985.

FERNANDES, J. M. As cidades de São Tomé e Santo Antônio, até aos séculos XIX XX: arquitectura e urbanismo. In: ROQUE, A. C. et al. (Org.) Actas do Colóquio Internacional São Tomé e Príncipe numa perspectiva interdisciplinar, diacrónica e sincrónica. Lisboa: Instituto Universitário de Lisboa; Centro de Estudos Africanos, 2012.

FONSECA, J. Religião e liberdade. Os negros nas irmandades e confrarias portuguesas (XV a XIX). Ribeirão: Húmus, 2016. 
HOONAERT, E. O cristianismo moreno no Brasil. Petrópolis: Vozes, 1991

KARASCH, M. C. Africanos escravizado: identidade e trabalho nas cidades do Brasil. In: PEDROSA, A. et al. (Org.) Histórias afro-atlânticas: antologia. São Paulo: Masp, 2018. v.2.

LEITE, S. História da Companhia de Jesus no Brasil (1938). Tomo II - Livro III. São Paulo: Edições Loyola, 2004.

LUNA, F. V. et al. (Org.) Escravagismo em São Paulo e Minas Gerais. São Paulo: Edusp, Imprensa Oficial do Estado de São Paulo, 2009.

MARTINS, A. E. São Paulo Antigo - 1554 a 1910. São Paulo: Paz Terra, 2003.

MARX, M. Nosso chão: do sagrado ao profano. Série espaço \& Desenho. História da Urbanização. São Paulo: Edusp, 1989.

MELLO E SOUZA, M. de. Catolicismo negro no Brasil: santos e minkisi, uma reflexão sobre miscigenação cultural. Revista Afro-Ásia, n.28, p.125-46, 2002.

Reis negros no Brasil escravista. História da Festa da Coroação do Rei do Congo. Belo Horizonte: Editora UFMG, 2006.

MEREDITH, M. O destino da África. Cinco mil anos de riquezas, ganância e desafios. Trad. Marlene Suano. Rio de Janeiro: Zahar, 2017.

MOREIRA, R. História das fortificações portuguesas no mundo. Lisboa: Publicações Alfa S.A, 1989.

OLIVEIRA, A. J. M. de. Devoção negra: santos pretos e catequese no Brasil colonial. Rio de Janeiro: Quartet; Faperj, 2008.

QUINTÃO, A. A. Irmandades Negras: outro espaço de luta e resistência (1870-1890). São Paulo: Annablume; Fapesp, 2002.

ROLNIK, R. A cidade e a lei: legislação, política urbana e territórios na cidade de São Paulo. São Paulo: Nobel, 1997.

ROWER, B. (Frei) Páginas da História Franciscana no Brasil. Petrópolis: Vozes, 1941.

SILVA, M. B. N. da. (Org.) História de São Paulo Colonial. São Paulo: Editora Unesp, 2008.

SILVA, T. M. da. A cidade de São Tomé no quadro das cidades insulares atlânticas de origem portuguesa. In. ROQUE, A. C. et al. (Org.) Actas do Colóquio Internacional São Tomé e Príncipe numa perspectiva interdisciplinar, diacrónica e sincrónica. Lisboa: Instituto Universitário de Lisboa; Centro de Estudos Africanos, 2012.

THORNTON, J. The Development of an African Catholic Church in the Kingdom of Kongo, 1491-1750. The Journal of African History, v.25, n.2, p.147-67, 1984.

A África e os africanos na formação do mundo atlântico (1400-1800). 5.ed. São Paulo: Campus; Elsevier, 2004.

VIANNA FILHO, L. O negro na Babia (um ensaio clássico sobre a escravidão). 4.ed. Salvador: EDUFBA: Fundação Gregório de Mattos, 2008.

VIEIRA, D. R. História do Catolicismo no Brasil. (1500-1889). Aparecida: Santuário, 2016. v.1. 
RESUMO - No século XIX, auge da presença dos negros na cidade de São Paulo, quatro Irmandades de Homens Pretos se inseriam no plano urbano, demarcando os lugares onde a população excluída poderia estabelecer redes de sociabilidade, preservando ainda referenciais africanos. O fluxo de devotos negros nessas e nas outras igrejas permitiria o estabelecimento de territórios do Catolicismo Negro em São Paulo, considerados como gêneses da presença urbana negra nesta cidade. Para além da apresentação desses marcos arquitetônicos e reconhecimento desses lugares da cena religiosa dos Oitocentos, o exercício de identificá-los a partir dos documentos primários tem como fim último revelar traços de uma história urbana ainda silenciada.

PALAVRAS-CHAVE: Catolicismo Negro, Igrejas das Irmandades dos Homens Pretos, Negros em São Paulo, Século XIX, Urbanismo.

ABSTRACT - In the $19^{\text {th }}$ century, during the peak of the presence of blacks in the city of São Paulo, four Brotherhoods of Black Men inserted themselves into the urban plan, demarcating the places where the excluded population could socialize and preserve their African references. The flow of black devotees in these and other churches would allow the establishment of territories of Black Catholicism in São Paulo, deemed as the genesis of black urban presence in this city. In addition to presenting these architectural landmarks and acknowledging them as sites of the religious scene of the 1800s, the exercise of identifying them from primary documents aims to reveal traces of a still-silenced urban history.

KErWORDS: Black Catholicism, Black Brotherhoods, Blacks in São Paulo, $19^{\text {th }}$ Century, Urbanism.

Fabricio Forganes Santos é mestrando em Arquitetura e Urbanismo do Programa de Pós-Graduação em Arquitetura e Urbanismo (PPGArq) da Faculdade de Arquitetura, Artes e Comunicação da Universidade Estadual Paulista "Júlio de Mesquita Filho" (FAAC/Unesp - Campus de Bauru). Pesquisador membro do grupo de pesquisa "Barroco Cifrado: Pluralidade Cultural na Arte e na Arquitetura das Missões Jesuíticas no território do Estado de São Paulo (1549-1759)", sediado na FAU-USP.

@ - fabricio.forg@gmail.com / https://orcid.org/0000-0002-1540-5858.

Recebido em 15.5.2020 e aceito em 5.3.2021.

I Universidade Estadual Paulista "Júlio de Mesquita Filho", Programa de Pós-Graduação em Arquitetura e Urbanismo, Faculdade de Arquitetura, Artes e Comunicação, Universidade Estadual Paulista "Júlio de Mesquita Filho", Bauru, São Paulo, Brasil. 